\title{
REPENSANDO A EFICÁCIA DOS DIREITOS FUNDAMENTAIS NAS RELAÇÕES JURÍDICAS PRIVADAS
}

\author{
VOLVIENDO A PENSAR LA EFICACIA DE LOS DERECHOS FUNDAMENTALES \\ EN LAS RELACIONES JURÍDICAS PRIVADAS
}

\begin{abstract}
${ }^{1}$ Thiago Penido Martins
RESUMO

Hodiernamente, uma das temáticas mais controversas e que tem despertado o interesse de inúmeros estudiosos é aquela relativa à eficácia dos direitos fundamentais no âmbito das relações jurídicas entre particulares, em especial, quando o objetivo é definir a extensão da eficácia dos direitos fundamentais nessas relações jurídicas. A questão da eficácia dos direitos fundamentais nas relações jurídicas entre particulares assume especial relevo, haja vista que seu estudo demandará, necessariamente, a análise das relações existentes entre as normas jurídicas constitucionais e as normas jurídicas de direito privado, bem como o conflito entre direitos fundamentais no âmbito de relações jurídicas privadas. $\mathrm{O}$ trabalho tem o desiderato de proceder ao estudo da eficácia dos direitos fundamentais no âmbito das relações jurídicas entre particulares, com o intuito de contribuir para o desenvolvimento dos debates existentes e aperfeiçoamento das construções teóricas que foram desenvolvidas ao longo das últimas décadas, na tentativa de formular proposições adequadas, capazes de conciliar os direitos fundamentais em conflito no âmbito de relações jurídicas privadas.
\end{abstract}

Palavras-chave: Direitos fundamentais, Direito privado, Eficácia dos direitos fundamentais

\section{RESUMEN}

En la actualidad, una de las temáticas más controversas y que ha despertado el interés de incontables estudiosos es aquella relativa a la eficacia de los derechos fundamentales en el ámbito de las relaciones jurídicas entre particulares, en especial, cuando el objetivo es definir la extensión de la eficacia de los derechos fundamentales en esas relaciones jurídicas. La cuestión de la eficacia de los derechos fundamentales en las relaciones jurídicas entre particulares asume especial relieve, haya vista que su estudio demandará, necesariamente, el análisis de las relaciones existentes entre las normas jurídicas constitucionales y las normas jurídicas de derecho privado, así como el conflicto entre derechos fundamentales en el ámbito de relaciones jurídicas privadas. El trabajo tiene el desiderato de proceder al estudio de la eficacia de los derechos fundamentales en el ámbito de las relaciones jurídicas entre particulares, con el objetivo de contribuir para el desarrollo de los debates existentes y perfeccionamiento de las construcciones teóricas que fueron desarrolladas al largo de las últimas décadas, en la tentativa de formular proposiciones adecuadas, capaces de conciliar los derechos fundamentales en conflicto en el ámbito de relaciones jurídicas privadas.

Palabras-claves: Derechos fundamentales, Derecho privado, Eficacia de los derechos fundamentales

\footnotetext{
${ }^{1}$ Doutor em Direito pela Pontifícia Universidade Católica de Minas Gerais - PUC, Belo Horizonte. Professor de Cursos de Graduação e Pós-Graduação em Direito pela Pontifícia Universidade Católica de Minas Gerais - PUC. Email: tutortreinamento@gmail.com
} 


\section{INTRODUÇÃO}

Hodiernamente, uma das temáticas mais controversas e que tem despertado o interesse de inúmeros estudiosos é aquela relativa à eficácia dos direitos fundamentais no âmbito das relações jurídicas entre particulares, em especial, quando o objetivo é definir a extensão da eficácia dos direitos fundamentais nessas relações jurídicas. A questão da eficácia dos direitos fundamentais nas relações jurídicas entre particulares assume especial relevo, haja vista que seu estudo demandará, necessariamente, a análise das relações existentes entre as normas jurídicas constitucionais e as normas jurídicas de direito privado, bem como o conflito entre direitos fundamentais no âmbito de relações jurídicas privadas.

O trabalho tem o desiderato de proceder ao estudo da eficácia dos direitos fundamentais no âmbito das relações jurídicas entre particulares, com o intuito de contribuir para o desenvolvimento dos debates existentes e aperfeiçoamento das construções teóricas que foram desenvolvidas ao longo das últimas décadas, na tentativa de formular proposições adequadas, capazes de conciliar os direitos fundamentais em conflito no âmbito de relações jurídicas privadas.

\section{A EFICÁCIA DOS DIREITOS FUNDAMENTAIS E RELAÇÕES JURÍDICAS ENTRE PARTICULARES}

O estudo da eficácia dos direitos fundamentais nas relações jurídicas privadas é, de certa forma, recente. Os primeiros estudos sobre a vinculação dos particulares aos direitos fundamentais somente surgiram em meados do século XX, a partir de importantes obras autores alemães. ${ }^{1}$ No direito brasileiro, a questão da eficácia dos direitos fundamentais nas relações jurídicas privadas ainda é incipiente, sendo que as primeiras obras datam do início de

\footnotetext{
${ }^{1}$ DURIG, Gunther. GrundrechteundZivilrechtsprechung.In: Maunz, Theodor (Hrsg.); Vom Bonner GrundgesetzzurgesamtdeutschenVerfassung - Festschrift zum 75. Geburtstag von Hans Nawiasky, München, 1956. LEISNER, Walter. Grundrechte und privatrecht.Munique, 1960. HESSE, Konrad. Derecho constitucional y derecho privado. Ignácio Gutiérrez (Trad.). Madrid: Civitas, 1955, 88 p; NIPPERDEY, Hans Carl. Allgemeinerteil des Bürgerlichenrechts.Tubanga, 1959. CANARIS, Claus-Wilhelm. Direitos fundamentais e direito privado. SARLET, Ingo Wolfgang; PINTO, Paulo Mota. (Trad.) Coimbra: Almedina, 2003.
} 
século $\mathrm{XXI}^{2}$, as quais, ainda assim, em sua maioria, tem como principal enfoque o estudo do fenômeno da constitucionalização do direito privado.

A temática da eficácia dos direitos fundamentais nas relações jurídicas privadas adquiriu relevância a partir do reconhecimento da existência do fenômeno do poder social, ou seja, a partir da constatação de que não só o Estado, mas também os particulares, são capazes de restringirem e vulnerarem os direitos fundamentais de outros particulares em suas relações jurídicas privadas. Os particulares, ao praticarem atos jurídicos, possuem a capacidade de condicionar, restringir e até inviabilizar o exercício de direitos fundamentais por seus semelhantes, capacidade que é potencializada quando se esta diante de relações jurídicas em que um dos sujeitos é detentor de uma posição privilegiada.

A constatação de que o poder social também constitui uma séria ameaça à eficácia dos direitos fundamentais, deu origem a um movimento para a reformulação da concepção clássica dos direitos fundamentais segundo a qual estes constituiriam direitos de defesa ou liberdades públicas, atuando apenas como limites ao exercício do poder estatal sobre a esfera privada do existir humano. ${ }^{3}$ A reformulação dessa concepção clássica representa importante avanço para a evolução da teoria dos direitos fundamentais e para o desenvolvimento do constitucionalismo, ao se reconhecer a capacidade das normas de direitos fundamentais de irradiarem seus efeitos para todas as relações jurídicas, ampliando o seu lastro protetivo.

A eficácia dos direitos fundamentais nas relações jurídicas entre particulares não se concretiza de idêntica forma àquela verificada nas relações jurídicas entre o particular e o poder estatal, uma vez que nas relações jurídicas entre particulares estar-se-á diante de uma relação jurídica caracterizada pelo fato de ambos os sujeitos serem igualmente titulares de direitos fundamentais. Essa peculiar característica é que torna a questão da eficácia dos direitos fundamentais nas relações jurídicas privadas mais tormentosa, configurando, em

2 TEPEDINO, Gustavo. Introdução: Código Civil, os chamados microssistemas e a Constituição: premissas para uma reforma legislativa. In: TEPEDINO, Gustavo. (Org.). Problemas de Direito CivilConstitucional. Rio de Janeiro: Renovar, 2000. SILVA, Virgílio Afonso da.A constitucionalização do direito: os direitos fundamentais nas relações entre particulares. São Paulo: Mandamentos, 2008. STEINMETZ, Wilson. A vinculação dos particulares a direitos fundamentais. São Paulo: Malheiros Editores, 2004. SARLET, Ingo Wolfgang. A Constituição concretizada: construindo pontes entre o público e o privado. Porto Alegre: Livraria do Advogado, 2000. MARTINS-COSTA, Judith (Org.). A reconstrução do Direito Privado. São Paulo: Revista dos Tribunais, 2002.

${ }^{3}$ A concepção segundo a qual os direitos fundamentais constituíam direitos subjetivos ou liberdades públicas subjetivas foi elaborada por George Jellinek, no final do século XIX, em obra intitulada Sistema dos Direitos Públicos Subjetivos, obra influenciada pelo pensamento individualista e positivista reinante à época e que influenciou diversas obras sobre os direitos fundamentais. Sua teoria concebia os direitos fundamentais apenas sob a perspectiva subjetiva e se baseava na ideia de que os direitos fundamentais assegurariam aos indivíduos, em suas relações com o poder estatal, quatro diferentes status jurídicos, quais sejam, status subiecciones, status negativus, status activus e status positivus. 
essência, um problema de conflito de direitos fundamentais ocorrido no tráfico privado, pois, "se os direitos fundamentais atuam a favor e contra todas as partes de uma relação jurídicoprivada, produzir-se-á ordinariamente uma colisão de direitos fundamentais." ${ }^{4}$ Assim, "como dos dois lados estão titulares de direitos fundamentais e direitos fundamentais em oposição, toda a argumentação a favor de uma posição jusfundamental pode ser replicada com os mesmos ou idênticos fundamentos a favor da outra posição jusfundamental em confronto."

Para Prieto Sanchis:

Certamente, tudo parece indicar que a eficácia dos direitos fundamentais não se mostra com idêntica força na esfera pública e na esfera privada, e justamente pela presença da autonomia da vontade. Mas nem tanto porque a dita autonomia sirva para renunciar aos direitos por parte de seu titular, mas sim porque representa em si mesma um direito fundamental da outra parte na relação jurídica. Em suma, minha opinião é que os direitos fundamentais no âmbito do direito privado se mostram sempre em conflito, porque frente à sua eficácia se alça sempre outro direito fundamental, o direito da outra parte (PRIETO SANCHIS, 1994, p.32, tradução nossa). ${ }^{6}$

Não se pode olvidar que da mesma forma que existem normas veiculadoras de direitos fundamentais que se destinam exclusivamente a limitar o exercício do poder estatal, sendo, portanto, inoponíveis aos particulares ${ }^{7}$, existem outras que, em razão de sua estrutura ou finalidade, foram pensadas e concebidas especialmente para produzirem seus efeitos no âmbito das relações jurídicas entre particulares. ${ }^{8}$ É o que se verifica, por exemplo, no que diz

\footnotetext{
${ }^{4}$ HESSE, 1955, p.60.

${ }^{5}$ NOVAIS, 2007, p. 323.

${ }^{6}$ Conforme original: "Ciertamente, todo parece indicar que laeficacia de losderechosfundamentales no se muestraconidénticafuerzaenla esfera pública y enla privada, y justamente por la presencia de la autonomia de lavoluntad. Pero no tanto porque dicha autonomia sirva para renunciar a losderechos por parte de su titular, sino porque representa ensímismaunderecho fundamental de laotra parte enlarelación jurídica privada. En suma, mi opinión es que losderechosfundamentalesenélámbitodelDerecho privado se muestramsiempreen conflito, porque frente a sueficacia se alzasiempreotroderecho fundamental, elderecho de laotra parte."
}

${ }^{7}$ Cite-se, por exemplo, as garantias de direito à informação, direito de petição, inafastabilidade da jurisdição.

8 Interessante destacar o entendimento de Sarmento para quem, que desde o advento das teorias contratualistas, os direitos fundamentais tinham por objetivo proteger os indivíduos de seus pares, sendo, inclusive, esta uma das justificativas para a criação do Estado, que assume o dever de lhes garantir os direitos fundamentais e protegê-los contra as violações perpetradas por outros particulares e pelo próprio poder público. Esse entendimento representa importante enfoque crítico sobre a concepção clássica dos direitos fundamentais como liberdades públicas, defendida por séculos por constitucionalistas, especialmente pela doutrina alemã. Sarmento desenvolve críticas contudentes à concepção clássica dos direitos fundamentais, em especial quanto a concepção de que os direitos fundamentais constituiriam apenas limites ao poder estatal, assim se manifestando: "Sem embargo, a própria origem contratualista das teorias sobre os direitos humanos induz a ideia de que, na 
respeito ao direito de liberdade de associação, liberdade de contratação, direito de indenização por dano material ou moral em razão da violação do direito ao nome, imagem ou honra ocasionada por ato ilícito, dentre outros. Assim, ao mesmo tempo em que esses direitos se destinam a impor limites à atuação do poder público, também servirão de fundamento para impor restrições ao agir dos particulares, que deverão respeitá-los. ${ }^{9}$

Perez Luño, destaca a necessidade de se reformular a concepção clássica dos direitos fundamentais, a qual, partindo do pressuposto de uma igualdade formal entre os indivíduos, ignorava a capacidade dos particulares, restringirem de forma abusiva e, portanto, ilícita, os direitos fundamentais de outros particulares no âmbito de suas relações jurídicas privadas. Nesse sentido, a partir do reconhecimento de que os particulares também constituem ameaças a integridade dos direitos fundamentais, Perez Luño assevera a necessidade de se superar a concepção clássica dos direitos fundamentais, alicerçada na concepção formal da igualdade, para reconhecer sua eficácia nas relações jurídicas entre particulares, ao assim se manifestar:

\begin{abstract}
Em sua dimensão subjetiva, os direitos fundamentais determinam o estatuto jurídico dos cidadãos, da mesma forma em suas relações com o Estado e as relações entre si. Tais direitos tendem, portanto, a tutelar a liberdade, a autonomia e a segurança da pessoa não só frente ao poder, mas também frente aos demais membros do corpo social. Concebidos inicialmente como instrumentos de defesa dos cidadãos frente à onipotência do Estado, se considerou que os direitos fundamentais não teriam razão de ser nas relações entre sujeitos do mesmo nível em que se desenvolvem as relações particulares. Este pensamento obedecia a uma concepção puramente formal da igualdade entre os diversos membros da sociedade. Mas é um fato notório que na sociedade neocapitalista essa igualdade formal não supõe uma igualdade material, e que nela o pleno desfrute dos direitos fundamentais se vê, em muitas ocasiões, ameaçado pela existência na esfera privada de centro de poder não menos importantes aqueles que correspondem aos órgãos públicos (PEREZ LUÑO, 2007, p. 22-23, tradução nossa). ${ }^{10}$
\end{abstract}

concepção dos filósofos inspiradores do constitucionalismo, tais direitos também valiam no âmbito das relações privadas. De fato, se os direitos eram naturais e precediam a criação do Estado, é evidente que eles podiam ser invocados nas relações privadas, até porque, num hipotético Estado de Natureza, inexistiria poder público. Sob esta ótica, a criação do Estado através do contrato social não desvirtuava tal situação, pois o que justificava o poder estatal era exatamente a necessidade de proteção dos direitos do homem, em face de seus semelhantes. Portanto, nas doutrinas jusnaturalistas, os direitos naturais valiam erga omnes, sendo concebidos como direitos de defesa do homem também em face de outros indivíduos e não apenas do Estado" (SARMENTO, 2008, p. 12).

${ }^{9}$ Em sentido idêntico: "La distinción entre Derecho público y privado, conla hegemonia de este, como expresión jurídica de la autonomia de lavoluntad de la burguesia. Así, losderechosfundamentalesen sus primeras etapas se concebían como derechos de los privados, propriedad y liberdad, como "disfrute pacífico de laindependencia individual" al decir de Constant, que identifica asílo que llamalalibertad de los modernos."(PECES-BARBA MARTINEZ, 1999, p. 138).

10 Conforme original: "Ensudimensión subjetiva, losderechosfundamentalesdeterminanel estatuto juridico de losciudadanos, lomismo em sus relaciones conel Estado que em sus relaciones entre si. 
A extensão eficácia dos direitos fundamentais às relações jurídicas privadas é também fruto de profundas transformações no constitucionalismo. O ponto de partida para o reconhecimento da eficácia dos direitos fundamentais nas relações jurídicas privadas está na superação da concepção unidirecional dos direitos fundamentais que, sob a égide do constitucionalismo liberal, compreendia os direitos fundamentais como direitos subjetivos públicos, oponíveis unicamente ao poder estatal. Essa concepção restritiva criava relevante contradição para o ordenamento jurídico, ao admitir que os direitos fundamentais positivados no texto constitucional fossem eficazes nas relações jurídicas com o poder estatal e ineficazes nas relações jurídicas privadas, permitindo aos particulares ampla liberdade para violarem os direitos fundamentais, dando azo a uma dupla ética social e jurídica. ${ }^{11}$

Há que se destacar, que no marco do constitucionalismo liberal, ao lado dos direitos fundamentais e do princípio da separação de poderes, importantes mecanismos constitucionais de limitação do poder estatal, o princípio da legalidade assume relevante papel. Como não se reconhecia aos direitos fundamentais a capacidade para produzirem efeitos nas relações jurídicas entre particulares, haja vista que não se atribuía às normas constitucionais força normativa e irradiante, a lei se transformou em instrumento de garantia dos direitos fundamentais nas relações jurídicas privadas, competindo-lhe disciplinar a forma de sua

Tales derechostienden, por tanto, a tutelar lalibertad, autonomia y seguridad de la persona no sólo frente al poder, sino también frente a losdemásmiembrosdelcuerpo social. Concebidos inicialmente como instrumentos de defensa de losciudadanos frente a laomnipotenciadel Estado, se considero que losderechosfundamentales no teníanrazón de ser em las relaciones entre sujetosdelmismo rango donde se desarrollan nas relaciones entre particulares. Este planteamiento obedecia a una concepción puramente formal de laiguadad entre los diversos miembros de la sociedade. Pero es unhecho notório que enlasociedad neocapitalista esaigualdad formal no supone uma igualdad material, y que em ellael pleno disfrute de losderechosfundamentales se vê, enmuchas ocasiones, amenazado por la existência enla esfera privada de centros de poder no menos importantes que los que corresponden a losórganos públicos."

11 Analisando a teoria de Jellinek, Fernandes tece relavante crítica sobre ao sustentar que: "a teoria era por demais arraigada na perspectivaestatalista de abordagem do ordenamento jurídico (...) os direitos graviitavam sempre em função do Estado e das posições do individuo frente ao mesmo. Não que o Estado tenha perdido a centralidade, mas a mesma tende a ser relativizada sob perspectivas mais atuais (contemporâneas) do direito constitucional. Peter Harbele, por sua vez, objeta que a leitura de Jellinek é dicotômica, colocando em dois extremos a vida políticas e a vida privada, com quase que antagônicas. Tal tese é fruto, na verdade, de uma leitura que separa a sociedade do Estado, estabelecendo a sociedade civil como figura apolítica e hostil a qualquer intervenção estatal. Tal cisão figura ainda na oposição entre liberdade dos antigos e liberdade dos modernos. A primeira entendida a partir de Aristóteles, como proteção da participação nos negócios da polis, ao passo que a outra, a partir de Constant, reservada à proteção dos assuntos privados de cada indivíduo tomado como elemento isolado do todo social" (FERNANDES, 2014, p. 318). Esse também é o pensamento de CANOTILHO, 2003, p. 392. 
aplicação e sua eficácia no tráfico privado. ${ }^{12}$ Assim, no marco do constitucionalismo liberal, os direitos fundamentais tinham sua eficácia jurídica nas relações jurídicas entre particulares condicionada à intermediação legislativa. ${ }^{13}$ Conforme destaca Sarmento:

A noção de que a Constituição é uma norma jurídica, dotada de caráter imperativo, cujos comandos podem ser tutelados em juízo quando não forem espontaneamente respeitados, embora possa hoje parecer uma completa obviedade, demorou algum tempo para se firmar. Durante um bom período campeou, sobretudo na Europa, em razão da ausência de uma jurisdição constitucional, a idéia de que a Constituição conteria uma proclamação de princípios políticos, que dependeriam sempre o legislador para a produção de efeitos concretos (SARMENTO, 2008, p.50).

A partir do momento em que se reconhece que as normas constitucionais são dotadas de força normativa e, portanto, capazes de irradiar seus efeitos por todo ordenamento jurídico, em razão de sua supremacia hierárquica, dá-se início ao constitucionalismo contemporâneo. A mais relevante mudança verificada sob a édige do constitucionalismo contemporâneo, ocorrida na segunda metade do século XX, foi a afirmação do princípio da supremacia da Constituição, segundo o qual a validade de todo ato normativo está condicionada a sua conformidade com o texto constitucional. Em função do princípio da supremacia da Constituição e do reconhecimento da força normativa das normas constitucionais, a teoria dos direitos fundamentais passou por profundas transformações que ecoaram pelo ordenamento jurídico, inclusive com relevantes reflexos sobre as relações entre direito público e direito privado.

Nesse contexto é que os direitos fundamentais irão se emancipar e se autonomizar ante à lei. Se antes a eficácia dos direitos fundamentais estava condicionada à lei, movendo-se em seu âmbito, e dependente da normatização de seu conteúdo, agora é a lei que deverá se desenvolver em conformidade dos direitos fundamentais. Diga-se de passagem, que as normas constitucionais, em razão de sua força normativa, passam a produzir tanto efeitos negativos, ao condicionarem a atividade legiferante à estrita observância aos preceitos constitucionais, fundamento de sua validade, quanto efeitos vinculantes ou irradiantes, ao exigirem que o legislador potencialize a efetividade dos direitos fundamentais, adotando as medidas

\footnotetext{
12 Há que destacar que enquanto não se discutia a eficácia dos direitos fundamentais nas relações jurídicas entre particulares, não se reconhecendo a força normativa e irradiante das normas de direitos fundamentais nas relações jurídicas entre particulares, a proteção dos indivíduos era realizada pelas normas jurídicas de direito privado, as quais tutelam a liberdade, a propriedade, a vida, dentre outros direitos individuais.
}

${ }^{13}$ Em igual sentido, STEINMETZ, 2004, p.73 
necessárias para aumentar o seu lastro protetivo, em especial, mediante a atividade legislativa. Os direitos fundamentais adquirem a qualidade de direitos jurídico-constitucionais, irradiando efeitos também para as relações jurídicas privadas, conformando-as. ${ }^{14}$

Os direitos fundamentais, para além constituírem direitos subjetivos destinados a disciplinar as relações entre os indivíduos e o poder estatal, tem reconhecida a sua dimensão objetiva, sendo concebidos também como princípios objetivos do ordenamento jurídico, irradiando seus efeitos por todas as relações jurídicas, garantindo, inclusive, a unidade e sistematicidade do ordenamento jurídico. ${ }^{15} \mathrm{O}$ reconhecimento da dupla dimensão dos direitos fundamentais constitui, portanto, um dos mais relevantes pressupostos para o desenvolvimento dos estudos acerca da eficácia dos direitos fundamentais nas relações jurídicas privadas, contribuindo para a reformulação da visão clássica dos direitos fundamentais, para a relativização da dicotomia entre o direito público e direito privado, bem como para a reconstrução dos influxos existentes entre o texto constitucional e as normas jurídicas de direito privado, estando diretamente relacionado ao fenômeno da constitucionalização do direito. Sarmento ao analisar a superação da perspectiva subjetiva dos direitos fundamentais destaca que:

(...) os direitos fundamentais no constitucionalismo liberal eram visualizados exclusivamente a partir de uma perspectiva subjetiva, pois cuidava-se apenas de identificar quais pretensões o indivíduo poderia exigir do Estado em razão de um direito positivado na sua ordem jurídica. Sem desprezar esse papel dos direitos fundamentais, que não perdeu a sua essencialidade na teoria contemporânea, a doutrina vai agora desvelar uma outra faceta de tais direitos, que virá para agregar-Ihes novos efeitos e virtualidades: trata-

\footnotetext{
14 A eficácia irradiante dos direitos fundamentais irá se manifestar, sobretudo, mas não exclusivamente, no processo de interpretação das cláusulas gerais e conceitos jurídicos indeterminados, existentes nas normas infraconstitucionais, dentre eles, os conceitos de boa-fé, interesse público, ordem pública, bons costumes, abuso de direito, dentre outros, os quais, em razão de sua plasticidade, permitem a infiltração do conteúdo das normas constitucionais de direitos fundamentais.

${ }^{15}$ Conforme destacado por Sarlet, "em que pese o substancial consenso a respeito da existência de uma perspectiva objetiva dos direito fundamentais (pelo menos no âmbito da dogmática constitucional européia continental, importa consignar, desde já, que, no concernente ao seu conteúdo, significado e diversas implicações, ainda permanecerem sérias controvérsias na doutrina e jurisprudência, dissídio esse que se manifesta até mesmo na seara terminológica, em face das diversas denominações atribuídas à perspectiva objetiva dos direitos fundamentais." (SARLET, 2004, p.80). Dentre as várias terminologias adotadas para designar esse fenômeno, as mais usuais são: ordem objetiva de valores, sistema de valores ou direitos fundamentais como normas objetivas. Sobre a questão Fernandes aduz que "a dimensão objetiva (indo além das funções de cunho subjetivo tradicionalmente consagradas aos direitos fundamentais e não sendo apenas um reverso da medalha da dimensão subjetiva) se apresentaria como um verdadeiro reforço de juridicidade das normas de direitos fundamentais, bem como da sistemática de concretização e densificação das mesmas." (FERNANDES, 2014, p. 309).
} 
se da chamada dimensão objetiva dos direitos fundamentais (SARMENTO, 2008, p. 105). ${ }^{16}$

Vale, ao analisar as funções subjetiva e objetiva dos direitos fundamentais, tece as seguintes considerações:

Os direitos fundamentais, assim, visam, em primeira linha, à satisfação de interesses próprios dos titulares. Conferem aos indivíduos pretensões a que sejam realizadas ações ou omissões tendentes a assegurar os valores e bens constitucionais que lhes são conferidos pelas normas constitucionais. Como direitos subjetivos, os direitos fundamentais delimitam posições jurídicas individuais em face do Estado. (...) Por outra perspectiva, a dimensão objetiva traduz-se na fundamentação dos direitos fundamentais como valores, regras ou princípios possuidores de validez objetiva, absoluta, universal, independentemente da experiência dos indivíduos. Com esse entendimento, normas de direitos fundamentais prescrevem deveres objetivos de forma a não se referirem a qualquer titular concreto (VALE, 2004, p.78). ${ }^{17}$

Neste contexto, em que se promove a releitura da concepção clássica dos direitos fundamentais, antes concebidos apenas como direitos subjetivos, para lhes compreender também como princípios objetivos do ordenamento jurídico, é que surge a teoria dos deveres de proteção ${ }^{18}$. Segundo a teoria dos deveres de proteção, também denominada de teoria dos imperativos de tutela, os direitos fundamentais, além de imporem abstenções ao exercício do

${ }^{16}$ Aduz Perez Luño, "Enel horizonte del constitucionalismo actuallosderechosdesempeñan, portanto, uma doble función: enel plano subjetivo siguenactuando como garantias de lalibertad individual, si bien a este papel clásico se aúnaahorala defensa de los aspectos sociales y colectivos de lasubjetividad, mientras que enel objetivo hanasumido una dimensión institucional a partir de lacualsucontenidodebefuncionalizarse para laconsecución de los fines y valores constitucionalmente proclamados." (PEREZ LUÑO, 2007, p.25). No mesmo sentido (VALE 2004, p.77). Conforme destaca Mendes: "A dimensão objetiva resulta do significado dos direitos fundamentais como princípios básicos da ordem constitucional (...) o aspecto objetivo dos direitos fundamentais comunica-lhes, também, uma eficácia irradiante, o que os converte em diretriz para a interpretação das normas dos demais ramos do Direito. A dimensão objetiva enseja, ainda, a discussão acerca da eficácia horizontal dos direitos fundamentais - a eficácia desses direitos na esfera privada, no âmbito das relações jurídicas entre particulares."(MENDES, 2011, p. 190-191).

${ }^{17}$ Em igual sentido Andrade: "Partindo-se do postulado de que os direitos fundamentais, na sua dimensão subjetiva, se referem exclusivamente às relações entre os particulares e o Estado, concluise que será na sua dimensão objetiva, enquanto normas constitucionais e valores comunitários, que se justifica e exprime a respectiva eficácia fora do âmbito dessas relações, em especial nas relações dos particulares entre si." (ANDRADE, 1998, p.141). E Sarmento: "No mesmo diapasão, afirma-se que a dimensão objetiva expande os direitos fundamentais para o âmbito das relações privadas, permitindo que estes transcendam o domínio das relações entre cidadão e Estado, às quais estavam confinados pela teoria liberal clássica. Reconhece-se então que tais direitos limitam a autonomia dos atores privados e protegem a pessoa humana da opressão exercida pelos poderes sociais não estatais, difusamente presentes na sociedade contemporânea." (SARMENTO, 2008, p.107).

${ }^{18}$ Canaris prefere o termo imperativos de tutela à deveres de proteção. 
poder estatal, lhe impõe o dever de proteger seus titulares de lesões e ameaças provindas de outros particulares, no âmbito de suas relações jurídicas privadas. Ao dissertar sobre a dupla função desempenhada pelos direitos fundamentais, Julio Estrada, destaca a importância do desdobramento da perspectiva objetiva dos direitos fundamentais para a ampliação do lastro protetivo aos seus titulares:

Esta dupla qualificação, na qual os dois elementos coexistem em uma relação de tensão, é resultado da implantação da denominada teoria objetiva, que redunda na ampliação do conteúdo dos direitos fundamentais, os quais não se limitam a atuar na relação do indivíduo com o poder público, mas sim, como valores supremos que valem para todo o ordenamento jurídico, também informam as relações recíprocas entre particulares, e limitam a autonomia privada, ao mesmo tempo que servem como mandatos de atuação e deveres de proteção para o Estado. (JULIO ESTRADA, 2000, p.66, tradução nossa). ${ }^{19}$

Sarlet disserta acerca da perspectiva objetiva dos direitos fundamentais como deveres de proteção ou imperativos de tutela, destacando a sua importância para o desenvolvimento da temática da eficácia dos direitos fundamentais nas relações jurídicas entre particulares:

\begin{abstract}
Além das funções já referidas e dos outros desdobramentos possíveis no âmbito da dimensão jurídico-objetiva e que aqui não teremos condição de desenvolver, assume relevo - notadamente em virtude de sua particular repercussão para a temática ora versada - a função atribuída aos direitos fundamentais e desenvolvida com base na existência de um dever geral de efetivação atribuído ao Estado (por sua vez, agregado à perspectiva objetiva dos direitos fundamentais) na condição de deveres de proteção (Schutzplichten) do Estado, no sentido de que a este incumbe zelar, inclusive preventivamente, pela proteção dos direitos fundamentais dos indivíduos não somente contra os poderes públicos, mas também contra agressões oriundas de particulares e até mesmo de outros Estados, função esta que muitos tratam sob o rótulo de função dos direitos fundamentais como imperativos de tutela, como prefere especialmente Canaris (SARLET, 2004, p.92-93).
\end{abstract}

A questão da eficácia dos direitos fundamentais nas relações jurídicas privadas é uma decorrência lógica da força normativa e irradiante das normas constitucionais sobre o

\footnotetext{
${ }^{19}$ Conforme original: "Esta doble cualificación, enlacuallos dos elementos coexistenen una relación de tensión, es el resultado de laimplantación de la denominada teoría objetiva, que redunda en una ampliacióndelcontenido de losderechosfundamentales. Los cuales no se limitan a actuar em larelacióndel individuo conel poder público, sino que, como valores supremos que rigen para todo elordenamiento jurídico, tambiéninformanlas relaciones recíprocas entre particulares, y limitanla autonomia privada, al mismotiempo que fungen como mandatos de actuación y deberes de protección para el Estado."
} 
ordenamento jurídico, dentre as quais estão as normas constitucionais veiculadoras de direitos fundamentais. Trata-se da superação da visão dicotômica do direito, segundo a qual direito público e direito privado seriam compartimentos estanques, impermeáveis e incomunicáveis, conforme fora sustentado pela doutrina alemã do século XIX.

Essa visão compartimentada do Direito, que predominou até meados do século $\mathrm{XX}$, partia do pressuposto de que as normas constitucionais não poderiam assumir uma função protetora ou garantidora de direitos fundamentais no âmbito de relações jurídicas privadas, uma vez que essas funções deveriam ser exercidas pelas normas jurídicas de direito privado, fato que explicava, à época, a propalada primazia do Direito Privado sobre o Direito Constitucional, bem como o dogma da completude do Direito Civil. Tratava-se de uma visão essencialmente legicêntrica que se assentava na crença da legitimidade dos parlamentos, enquanto órgãos de representação popular, para a criação das normas jurídicas e obrigações legais e na ilegitimidade dos órgãos jurisdicionais para a aplicação direta dos direitos fundamentais nas relações jurídicas privadas. ${ }^{20}$

No modelo oitocentista, às codificações civis competia disciplinar de forma detalhada as condutas humanas e suas consequências jurídicas, de modo que a função dos órgãos jurisdicionais deveria se limitar à realização de simples silogismos jurídicos, à análise da subsunção dos fatos às normas jurídicas. Nesse contexto, acreditava-se na onipotência dos órgãos legislativos e no servilismo dos órgãos jurisdicionais à lei, decorrente de uma concepção clássica do princípio da separação dos poderes. ${ }^{21}$ Aos órgãos jurisdicionais competiria apenas aplicar o direito, a norma jurídica, sendo vedada qualquer atividade hermenêutica construtiva.

Ao fim da Segunda Guerra Mundial, a relação entre direito público e privado passa por uma "mutação qualitativa essencial",22, caracterizada pela completa alteração das funções desempenhadas pelas normas jurídicas de direito público e de direito privado. Essa mudança é

20 Conforme destaca Salvador Coderch: "nadieniegahoy seriamente la relevância de laConstituciónenlas normas delDerecho Privado nisuaplicación judicial, nienlanecesidad de una concordancia pratica entre las normas sobre derechosfundamentales y elDerecho Privado o de conciliar el alcance de los distintos derechosfundamentalescuando se produce una colisión entre ellosenelámbito de uma relación privada negocial o extranegocial." (SALVADOR CORDECH, 1997, p. 99)

${ }^{21}$ Atualmente muito se discute acerca do conteúdo do princípio da separação de poderes e das funções a serem desempenhadas pelos órgãos legislativos e jurisdicionais. Em decisão proferida no julgamento do Mandado de Injunção n..-, o Supremo Tribunal Federal destaca a necessidade de se revistar o conteúdo do princípio da separação dos poderes e superar a sua concepção clássica, segundo a qual.

${ }^{22}$ QUEIROZ, 2010, p. 363. 
marcada pela passagem de uma "originária justaposição amplamente incomunicada" entre direito público e direito privado, para uma "relação de recíproca complementariedade e dependência" ${ }^{23}$. O próprio fenômeno da constitucionalização do direito privado surge a partir do reconhecimento da necessidade de se reinterpretar essa visão clássica e dicotômica da ciência jurídica, superando a compreensão dos direitos fundamentais como direitos de defesa ou liberdades públicas subjetivas oponíveis apenas ao poder estatal, desconsiderando a sua força normativa irradiante, sua dimensão objetiva e sua capacidade de produzir efeitos no âmbito de relações jurídicas privadas. ${ }^{24}$

Há que se destacar a importância da evolução da teoria dos direitos fundamentais para o processo de superação e desconstrução da dicotomia entre direito público e privado, uma vez que, conforme destaca Leisner ${ }^{25}$, neste contexto em que o texto constitucional adquire centralidade perante o ordenamento jurídico, outrora ocupada pelo Direito Civil, os direitos fundamentais transformam-se em indispensáveis pontos de conexão entre a Constituição e o Direito Privado. O próprio Código Civil, acompanhando as mudanças promovidas pelo constitucionalismo contemporâneo e evolução dos direitos fundamentais, passou a dedicar alguns de seus dispositivos à proteção dos direitos de personalidade, os quais, em sua essência, também estão assegurados como direitos fundamentais pelo texto constitucional. Essa inserção de normas protetivas dos direitos da personalidade no Direito Privado contribuiu para o processo de personalização do Direito Privado e consequente matização da patrimonialidade até então dominante.

A dicotomia entre público e privado traz consigo a falsa ideia de que o direito público se restringiria a disciplinar as relações entre particulares e o poder público, quando o próprio texto constitucional contém diversas normas constitucionais que possuem como titulares particulares, tutelando-os no âmbito de suas relações jurídicas privadas. Numerosos são os preceitos constitucionais relativos aos direitos fundamentais que possuem como destinatários particulares em suas relações jurídicas privadas. Esse processo de relativização da dicotomia entre público e privado é marcado por uma profunda mudança nas relações entre as normas constitucionais, em especial, as normas de direitos fundamentais, e as normas jurídicas de

\footnotetext{
${ }^{23}$ HESSE, 1955, p. 32.

${ }^{24}$ Segundo destaca Canaris: "Em quase todo e qualquer ordenamento jurídico moderno, de modo mais ou menos cogente, coloca-se a questão da relação entre direitos fundamentais e o Direito Privado. Ela radica no fato de os direitos fundamentais, enquanto parte da Constituição, terem um grau mais elevado na hierarquia das normas do que o Direito Privado, podendo, por conseguinte, influenciá-Io." (CANARIS, 2003, p.9).

${ }^{25}$ LEISNER, Walter. Grundrechteundprivatrecht. Munique, 1960.
} 
direito privado, transferindo a posição de centralidade no ordenamento jurídico para o texto constitucional. ${ }^{26}$

O reconhecimento da força normativa e supremacia hierárquica das normas constitucionais, com a consequente mudança do eixo interpretativo para o texto constitucional, não tem o condão de subtrair do direito privado a sua autonomia e importância no ordenamento jurídico. É importante reconhecer que da mesma forma que o direito público possui institutos e princípios que lhes são próprios, os quais são erigidos considerando as peculiares características das relações jurídicas que pretendem disciplinar, o direito privado também possui institutos e princípios que lhe são próprios e lhes dão essência, de modo que, mesmo diante do reconhecimento da força normativa e irradiante das normas constitucionais, é indispensável que o intérprete não desconsidere as normas de direito privado vigentes e a principiologia que lhe é inerente. ${ }^{27} 28$

${ }^{26}$ Conforme destaca Perlingeri: "O Código Civil certamente perdeu a centralidade de outrora, O papel unificador do sistema, tanto nos seus aspectos mais tradicionalmente civilísticos quanto naqueles de relevância publicista, é desempenhado de maneira cada vez mais incisiva pelo Texto Constitucional. Falar de descodificação relativamente ao Código vigente não implica absolutamente a perda do fundamento unitário do ordenamento, de modo a propor a sua fragmentação em diversos microordenamentos e em diversos microssistemas, com ausência de um desenho global." (PERLINGERI, 1999, p.6). Veja-se também, sobre o tema, as obras de: MORAES, Maria Celina Bodin de. A caminho de um direito civil constitucional, Revista de Direito Civil, no 65. p. 21-32. jul./set., 1993, pág. 22.; FACHIN, Luiz Edson. Teoria Crítica do Direito Civil. 2a ${ }^{\mathrm{a}}$. ed. Atual. Rio de Janeiro, Renovar, 2003a; TEPEDINO, Gustavo. Introdução: Código Civil, os chamados microssistemas e a Constituição: premissas para uma reforma legislativa. In: TEPEDINO, Gustavo. (Org.). Problemas de Direito Civil-Constitucional. Rio de Janeiro: Renovar, 2000. p. 1/16.; MARTINS-COSTA, Judith (Org.). A reconstrução do Direito Privado. São Paulo: Revista dos Tribunais, 2002; SARMENTO, Daniel Antonio de Moraes. A normatividade da constituição e a constitucionalização do Direito Privado. Revista da Escola da Magistratura do Estado do Rio de Janeiro, Rio de Janeiro, v. 6, n. 23, p. 272-297, 2003.

${ }^{27}$ Preleciona Canotilho, "A ordem jurídica privada não está, é certo, divorciada da Constituição. Não é um espaço livre de direitos fundamentais. Todavia, o direito privado perderá a sua irredutível autonomia quando as regulações civilisticas - legais ou contratuais - veem o seu conteúdo substancialmente alterado pela eficácia directa dos direitos fundamentais na ordem jurídica privada. $A$ Constituição, por sua vez, é convocada para as salas diárias dos tribunais com a consequência da inevitável banalização constitucional. Se o direito privado deve recolher os princípios básicos dos direitos e garantias fundamentais, também os direitos fundamentais devem reconhecer um espaço de auto-regulação civil, evitando transforma-se em direito de não liberdade do direito privado. $A$ nosso ver, o problema não está apenas nos perigos que espreitam as duas ordens constitucional e civil quando se insiste na conformação estrita e igualitarizante das relações jurídicas privadas pelas normas constitucionais." (CANOTILHO, 2006, p.211)

${ }^{28}$ Conforme destaca Nery: "As situações jurídicas privadas pautam-se pela igualdade e pela liberdade, enquanto que as situações jurídicas públicas têm embasamento em princípios diferentes, dos quais os da autoridade e da competência são os mais marcantes. Em virtude disso, os sujeitos de direitos, no âmbito das situações particulares, podem agir livremente no contexto das situações jurídicas que não Ihe sejam proibidas (atipicidade dos negócios jurídicos). Diferentemente se dá com o sujeito que realiza atos e negócios que se inserem no contexto do trato das coisas públicas, a quem se permite apenas a realização daquilo para cujo exercício esteja previamente autorizado (princípio da legalidade e tipicidade dos negócios de direito público)." (NERY, 2008, p. 172) 
Muitas são, todavia, as situações em que o direito público recorre aos institutos ou princípios inerentes ao direito privado, para atender a situações específicas. Canotilho adverte que mesmo diante dessa aproximação entre direito público e privado e dos influxos das normas constitucionais sobre o ordenamento jurídico, não se pode pretender transformar a Constituição em um supercódigo, nem reduzir o direito privado a um simples direito constitucional concretizado, competindo ao intérprete observar as especificidades e peculiaridades das relações jurídicas entre particulares e aquelas inerentes as relações entre os particulares e o poder público, bem como respeitar as decisões legislativas contidas nas normas jurídicas de direito privado decorrentes do livre exercício das competências constitucionais pelo legislador, desde que, obviamente, estejam em conformidade com o texto constitucional. $^{29}$

Nery aduz que a despeito a autonomia estrutural e principiológica existente entre direito público e direito privado, não se pode admitir e fomentar a existência de um dualismo dogmático-jurídico, no qual o direito público seja compreendido como o ordenamento do bem comum e o direito privado como uma ordem jurídica egoística e individualista de utilidade privada. O ordenamento jurídico não pode se orientar por princípios contraditórios sob penade perda de sua unidade e quebra de sua sistematicidade, compromentendo a segurança jurídica das relações sociais. ${ }^{30}$ Nessa perspectiva o texto constitucional assume a função de centro axiológico normativo do ordenamento jurídico, tornando-se responsável por promover e assegurar a unidade e harmonia normativa.

Sarmento $^{31}$, defensor da eficácia irradiante dos direitos fundamentais, analisando o fenômeno da constitucionalização do direito privado, tece relevantes observações acerca dos riscos de uma "panconstitucionalização" ou "constitucionalização metodologicamente descontrolada". Para o autor, a constitucionalização descontrolada e excessiva do direito privado poderia se apresentar antidemocrática, ao subtrair do povo, o direito de, mediante representantes eleitos e observado o devido processo legislativo, decidir sobre aspectos da vida privada, bem como provocar uma "anarquia metodológica", decorrente da utilização irracional e não intersubjetivamente controlável de preceitos constitucionais semanticamente vagos, abstratos e abertos na resolução dos casos concretos pelos órgãos jurisdicionais. Nesse sentido, Sarmento destaca que:

\footnotetext{
${ }^{29}$ CANOTILHO, 2006, p. 1288.

30 NERY, 2008, p. 172.

${ }^{31}$ SARMENTO, 2007, p. 115.
} 


\begin{abstract}
Muito mais que servos autômatos da lei, os juízes, sobretudo os investidos de jurisdição constitucional, tornaram-se guardiões dos direitos fundamentais e partícipes, em alguma medida, no próprio processo de criação do Direito - o que não deixa de suscitar uma série de questões complexas, seja no que tange à sua legitimação democrática, seja no que concerne aos cuidados metodológicos necessários à compatibilização deste ativismo com os postulados imanentes ao Estado de Direito, ligados à previsibilidade e à segurança jurídica (SARMENTO, 2007, p. 121).
\end{abstract}

Do mesmo modo que as normas jurídicas de direito privado devem ser interpretadas em conformidade com o texto constitucional, garantindo a unidade do ordenamento jurídico, deve-se atentar para a necessidade de se respeitar a competência decisória do legislador, no cumprimento de sua função constitucional de densificar e concretizar o conteúdo dos direitos fundamentais nas relações jurídicas entre particulares. $\mathrm{O}$ reconhecimento da força normativa, superioridade e fundamentalidade das normas constitucionais, tem o condão de proporcionarlhes a possibilidade de irradiarem seus efeitos por todo o tecido normativo, tornando questionável a visão liberal e clássica assentada na contraposição rígida entre direito público e direito privado. Ao irradiarem seus efeitos para todo o tecido normativo, as normas constitucionais ampliam a sua efetividade e promovem mudanças substantivas nas relações entre direito público e direito privado, entre as normas constitucionais e as normas de direito privado, viabilizando as discussões entorno da eficácia das normas de direitos fundamentais nas relações jurídicas entre particulares.

\title{
3 REPENSANDO A EFICÁCIA DOS DIREITOS FUNDAMENTAIS NAS RELAÇÕES JURÍDICAS PRIVADAS
}

A questão da eficácia dos direitos fundamentais nas relações jurídicas privadas exige a adoção de soluções diferenciadas, que não se limitem a defender de maneira uniforme o reconhecimento da eficácia imediata ou mediata. ${ }^{32}$ A exigência por soluções diferenciadas decorre, principalmente, do fato de que a questão deverá ser analisada considerando os direitos fundamentais em conflito, bem como as especificidades do caso concreto. Ademais, a questão da eficácia dos direitos fundamentais nas relações jurídicas entre particulares não deve ser analisada a partir do pressuposto de que eficácia imediata e mediata são formas

32 SILVA, 2008, p. 134; SARLET, 2009, p. 358. 
incompatíveis e excludentes de incidência dos direitos fundamentais nas relações jurídicas privadas, pois conforme destaca Andrade:

A análise concreta das soluções resultantes das diversas posições defendidas mostrava que as teorias, para além de estarem de acordo quanto à existência de uma vinculação, surgiam mitigadas, procurando cada uma conciliar ou adaptar sua tese central com os princípios ou situações que eram, afinal, os que fundavam a argumentação das outras. Por vezes, todas as teorias, partindo de pressupostos distintos ou operando por vias diversas, chegavam ao mesmo resultado prático (ANDRADE 2009, p. 239). ${ }^{33}$

A superação dessa visão dicotômica entre eficácia imediata e mediata perpassa pelo reconhecimento da multifuncionalidade e pluralidade de funções que exercem os direitos fundamentais, em especial, da capacidade de irradiarem seus efeitos por todo o ordenamento jurídico. Veiculados mediante normas constitucionais, os direitos fundamentais assumem uma posição privilegiada dentro do ordenamento jurídico, em razão de sua superioridade hierárquica, característica que exige que todas as demais normas jurídicas integrantes do ordenamento jurídico estejam em conformidade com o seu conteúdo. A construção de um modelo de contenha soluções diferenciadas, que transcendam a propalada dicotomia entre eficácia direta e indireta das normas de direitos fundamentais, pressupõe, de início, releitura da concepção clássica dos direitos fundamentais como direitos de defesa ou liberdades públicas oponíveis apenas ao poder público. ${ }^{34}$

É possível sustentar, em essência, que a questão da eficácia dos direitos fundamentais nas relações jurídicas privadas é uma decorrência lógica do fenômeno da constitucionalização do direito privado, que traz consigo a ideia de irradiação dos efeitos das normas constitucionais sobre o ordenamento jurídico, inclusive das normas constitucionais de direitos fundamentais. Ainda que, na atualidade, a irradiação de efeitos das normas constitucionais tenha adquirido maior aceitação, isso nem sempre ocorreu, principalmente em se tratando de

\footnotetext{
${ }^{33}$ Vale comunga no mesmo entendimento ao sustentar que, "o grande equívoco que paira sobre as construções teóricas a respeito da maneira como os direitos fundamentais influenciam a seara privada é, sobretudo, o fato de que cada teoria trata o assunto de forma a excluir as demais, como se eficácia mediata, imediata e eficácia produzida por direitos de defesa e de prestação fosse categorias inconciliáveis entre si. Cada construção teórica, portanto, concebe-se como única correta, negando as demais." (VALE, 2004, p. 170).

${ }^{34}$ Nesse sentido destaca Canotilho que, "o problema da eficácia dos direitos, liberdades e garantias na ordem jurídica privada tende hoje para uma superação da dicotomia eficácia mediata/imediata a favor de soluções diferenciadas" e conclui "essa eficácia, para ser compreendida com rigor, deve ter em consideração a multifuncionalidade e pluralidade de funções dos direitos fundamentais, de forma a possibilitar soluções diferenciadas e adequadas, consoante o referente direito fundamental que estiver em causa no caso concreto." (CANOTILHO, 2003, p. 1208-1209).
} 
irradiação de efeitos das normas constitucionais sobre o direito privado e as consequências sobre o primado a autonomia privada e tutela da liberdade contratual. ${ }^{35}$

A irradiação dos efeitos das normas constitucionais de direitos fundamentais por todo o ordenamento jurídico, inclusive sobre as relações jurídicas entre particulares, acaba por conduzir as discussões sobre a eficácia dos direitos fundamentais nas relações jurídicas privadas para a discussão acerca da colisão de direitos fundamentais concretizada no tráfico privado, em regra, traduzida pelo conflito entre a autonomia privada e os demais direitos fundamentais, que se desdobrará, ao final, na discussão relativa à constitucionalidade das limitações impostas aos direitos fundamentais no âmbito de relações jurídicas entre particulares em decorrência do exercício da autonomia privada.

A irradiação dos efeitos das normas de direitos fundamentais para as relações jurídicas privadas, não poderá desconsiderar que o direito privado possui principiologia própria, que não poderá ser distorcida ou deturpada. É por este motivo que o reconhecimento da eficácia dos direitos fundamentais nas relações jurídicas privadas deverá necessariamente considerar a importância de se proteger da autonomia privada e liberdade enquanto fontes e princípios basilares do Direito Privado, em especial, como fonte dos negócios jurídicos. ${ }^{36}$ A atividade legislativa, nessa perspectiva, deve cumprir importante função na concretização dos direitos fundamentais nas relações jurídicas privadas, em especial, em seu dever de conformar o exercício da autonomia privada compatibilizando-a com a proteção dos demais direitos fundamentais, limitando aquele exercício se dê de forma abusiva.

Conforme destaca Vale, independente do ponto de vista adotado, deve-se privilegiar o papel a ser desempenhado pelo legislador na densificação do conteúdo dos direitos fundamentais nas relações jurídicas entre particulares, uma vez que:

(...) não há maiores discussões sobre o papel preferencial exercido pelo legislador democrático na operação de acomodação dos direitos fundamentais no cenário privado. Não cabe dúvida, que tanto neste âmbito como no campo das relações entre indivíduo e Estado, a lei é o instrumento

\footnotetext{
${ }^{35}$ SILVA, 2008, p. 41.

${ }^{36}$ Conforme destaca Alexy, "o tribunal civil tem que levar em consideração os princípios de direitos fundamentais favoráveis às posições alegadas pelas partes; mas, de outro, ele também tem que aplicar o direito privado vigente, a não ser que ele seja incompatível com todas as possíveis interpretações dos princípios constitucionais. $O$ fato de não serem apenas os princípios de direitos fundamentais que tem que desempenhar um papel nos casos de efeitos perante terceiros, mas também o direito privado, é algo que pode ser percebido a partir da constatação de que os princípios, em muitos casos, aceitam diversas soluções como constitucionalmente possíveis, e de que o juiz não está submetido apenas à vinculação a princípios materiais, mas também a diversas outras vinculações, como, por exemplo, àquela que decorre do princípio formal do respeito às decisões do legislador democraticamente legitimado e da consideração dos precedentes." (ALEXY, 2014, p. 537)
} 
mais apropriado para essa função. Dessa forma, qualquer que seja a posição que se mantenha a respeito da eficácia dos direitos fundamentais nas relações privadas, o protagonismo do legislador é um dado unanimemente reconhecido (VALE, 2004, p. 76).

Silva também destaca a importância da atividade legislativa na concretização do conteúdo dos direitos fundamentais nas relações jurídicas entre particulares, ao assim prelecionar:

A existência de um Código Civil, cujas normas tem, em geral, a estrutura de regras, impede, prima facie, uma aplicabilidade direta dos direitos fundamentais às relações jurídicas entre particulares. Os efeitos desses direitos chegam às relações jurídicas entre particulares pela via indireta isto é, parar usar a expressão de DURIG, por meio do direito privado. O direito privado deve servir, nesse caso, de transporte para os direitos fundamentais às relações jurídicas entre particulares, o que exige, portanto, uma intepretação dos dispositivos jusprivados sempre tendo com base os princípios constitucionais (SILVA, 2008, p. 121).

A atividade legislativa nem sempre conseguirá disciplinar e concretizar o conteúdo das normas de direitos fundamentais nas relações jurídicas privadas, nem mesmo problematizar e estabelecer soluções prévias para todos os conflitos jurídicos possíveis. Nessas situações, em que o legislador for omisso, uma vez que não é plausível acreditar ou confiar em sua onisciência, os órgãos jurisdicionais assumirão a função de concretizar o conteúdo dos direitos fundamentais no âmbito daquela relação jurídica entre particulares, mediante a interpretação das cláusulas gerais ou conceitos jurídicos indeterminados, pela interpretação das normas jurídicas de direito privado vigentes em conformidade com o texto constitucional, ou, inclusive, pela aplicabilidade direta do conteúdo dos direitos fundamentais nas relações jurídicas privadas, em razão de sua dimensão objetiva e seu efeito irradiador. ${ }^{37}$

Inadequado, portanto, condicionar ou limitar a eficácia dos direitos fundamentais nas relações jurídicas privadas à prévia atividade mediadora concretizadora do legislador, dada a

37 Conforme destaca Sombra: "Não restam dúvidas, portanto, de que a lei consubstancia o mecanismo teoricamente mais apropriado, em termos de segurança jurídica e isonomia, para a concretização dos direitos fundamentais nas relações entre particulares, todavia, devem ser considerados dos aspectos de fundamental importância: a omissão inconstitucional e a incapacidade legislativa de dirimir todas as possíveis tensões entre direitos fundamentais em abstrato." (SOMBRA, 2004, p. 167) Bilbao Ubillos, reconhecido como defensor da eficácia direta dos direitos fundamentais, salienta a primazia da atividade legislativa, ao sustentar que: "Esta competencia se fundamentaria en dos argumentos, que me parecen válidos. En primer lugar, laconcreción legislativa de laeficacia entre particulares de losderechosfundamentales, mediante lapromulgación de leyes antidiscriminatórias, por ejemplo, comporta muchasveceslimitaciones de lalibertad individual, que deveríanimpornerse por el legislador. $Y$ en ele segundo lugar, el nível de vigência social de losderechosfundamentalesconstituye una opción de política legislativa porque laConstitución no impone um nível derterminado (...) sino unicamente un nível mínimo." (BILBAO UBILLOS, 1997, p. 292) 
impossibilidade de que este anteveja e contemple todas as situações e conflitos possíveis entre os direitos fundamentais. ${ }^{38}$ Bokenforde, sustenta que a eficácia dos direitos fundamentais nas relações jurídicas entre particulares não pode ficar refém e condicionada à normatização infraconstitucional, razão pela qual, diante da possibilidade de insuficiência normativa, bem como da inexistência de cláusulas gerais e conceitos jurídicos indeterminados, necessário admitir e reconhecer a eficácia direta das normas de direitos fundamentais nas relações jurídicas privadas, a partir das especificidades do caso concreto. ${ }^{39}$

Nesse sentido, Novais sustenta que a teoria da eficácia mediata não proporciona uma resposta satisfatória nos casos em que inexiste densificação legislativa, uma vez que, diante da omissão legislativa, os direitos fundamentais acabariam ficando completamente desprotegidos de possíveis agressões perpetradas por outros particulares, não sendo plausível e aceitável que em nome do princípio da separação de poderes ou da suposta proteção da autonomia do direito privado se justifique a impossibilidade dos órgãos jurisdicionais resolverem conflitos privados aplicando diretamente os direitos fundamentais positivados no texto constitucional. E conclui que:

\begin{abstract}
(...) se o princípio da autonomia privada fosse justificação suficiente para recusar a aplicação das normas constitucionais, permaneceria sem fundamento a própria instituição da jurisdição constitucional, pois a recusa de intervenção do judiciário numa situação de omissão legislativa teria, em rigor, de ser acompanhada de análoga recusa de possibilidade de controle de constitucionalidade da legislação civil (NOVAIS, 2007, p. 360).
\end{abstract}

Contrariamente ao que se possa pressupor, eficácia direta e indireta, são construções teóricas compatíveis e complementares, constituindo perspectivas de um mesmo fenômeno, a serem adotadas em situações e momentos distintos da irradiação dos direitos fundamentais para as relações jurídicas privadas. Por esse motivo, uma solução que se pretenda adequada e aspire contribuir para o desenvolvimento da eficácia dos direitos fundamentais nas relações jurídicas entre particulares, perpassará, necessariamente, pelo reconhecimento da coexistência de diversas formas de eficácia, cada qual se referindo a um determinado aspecto do problema, sem que deva existir qualquer pretensão de primazia entre si.

Para Alexy, a questão da eficácia dos direitos fundamentais nas relações jurídicas privadas se reduz, em última instância, ao conflito entre princípios ou bens constitucionais e, portanto, a uma questão de ponderação, na qual o mais relevante não é o como, mas sim, o

\footnotetext{
${ }^{38}$ Em igual sentido, SOMBRA, 2004, p. 168.

${ }^{39}$ BOKENFORD, 1993.
} 
resultado a ser alcançado, qual seja, o reconhecimento de que os direitos fundamentais são eficazes nas relações jurídicas entre particulares. Destaca Alexy, todavia, que por mais que os resultados sejam equivalentes ${ }^{40}$, independentemente da construção teórica adotada, tal fato não torna desnecessário o estudo da eficácia dos direitos fundamentais, dada a necessidade de se construir um modelo lógico que compatibilize e harmonize os principais contributos de cada uma das construções teóricas desenvolvidas, bem como seus aspectos mais relevantes, com o desiderato de tornar transparente e racional o processo hermenêutico de incidência dos preceitos de direitos fundamentais nas relações jurídicas privadas, observando, caso a caso, as especificidades fáticas e jurídicas, bem como o direito fundamental em questão.

Vale, também destaca a necessidade de se construir um modelo diferenciado para a questão da eficácia dos direitos fundamentais nas relações jurídicas entre particulares, a partir da superação da dicotomia entre eficácia direta e indireta, uma vez que, segundo o autor, "uma das principais razões pelas quais permanece pendente a polêmica a respeito de como incidem os direitos fundamentais no âmbito privado é o fato de as construções teóricas serem defendidas como se cada uma fosse a correta, de forma a se excluírem as demais"41, entendimento igualmente perfilhado por Canotilho $^{42}$, para quem a questão demanda a construção de soluções diferenciadas e Gutierrez ${ }^{43}$, que sustenta que as construções teorias da eficácia direta e indireta, além de razoáveis e compatíveis, por não produzirem resultados contraditórios, aspiram e postulam à aplicação coordenada e complementar. ${ }^{44}$ Novais ${ }^{45}$ destaca

\footnotetext{
${ }^{40}$ Segundo Alexy: "O fato de as três construções serem equivalentes nos resultados não significa que a questão acerca de sua correção seja irrelevante. A pergunta sobre como tem de ser pensado em cada caso o efeito dos direitos fundamentais e das normas de direitos fundamentais no direito civil é algo que deve ser respondido não apenas porque a Ciência do Direito não se satisfaz com a simples obtenção de resultados corretos ou aceitáveis, sem considerações acerca de sua construção, mas também porque sem uma construção correta não é possível um quadro preciso do efeito dos direitos fundamentais e das normas de direitos fundamentais no sistema jurídico." (ALEXY, 2014, p. 533) Em igual sentido, Bilbao Ubillos sustenta que não consegue enxergar diferenças entre as teorias da eficácia direta e indireta, ao assim se pronunciar: "no veoninguna, fracamente. A lamismasolución se puedellegar (con clausulas generales o sinellas) aplicando enel momento de interpretar las normas de derecho privado el principio general. El efecto de irradiación de losderechosfundamentalesenla esfera delderecho privado, no aporta, em realidade, nada de nuevo." (BILBAO UBILLOS, 2007, p. 313).

${ }^{41}$ VALE, 2004, p. 95.

${ }^{42}$ CANOTILHO, 2003, p. 1208

${ }^{43}$ GUTIERREZ, 2010, p. 22

${ }^{44}$ Conforme destaca Bydlinski, citado por Silva: "Se as normas de direitos fundamentais são aplicáveis diretamente ou se elas simplesmente adentram no direito privado por meio de seus conceitos e cláusulas gerais é questão que não tem necessariamente influência sobre o grau de relativização dos direitos fundamentais. Pode-se proceder, no sopesamento entre o direto fundamental envolvido e a liberdade individual, de forma mais rígida ou mais flexível e o mesmo pode ocorrer por intermédio da cláusula dos bons costumes (...) É possível se basear somente nas cláusulas gerais (...) nas cláusulas gerais combinadas com os artigos de direitos fundamentais ou
} 
que tanto a teoria da eficácia imediata, eficácia mediata e teoria dos deveres de proteção, a despeito de apresentadas como antagônicas, adotam a premissa de que competirá, inicialmente, aos órgãos legislativos, conformar o exercício da autonomia privada e liberdade contratual ao conteúdo dos direitos fundamentais.

A dicotomia entre eficácia direta e indireta acaba perdendo parte de seu sentido em ordenamentos jurídicos caracterizados pela coexistência dos controles concentrado e difuso de constitucionalidade. Ao se reconhecer que todos os juízos são dotados de jurisdição de constitucionalidade, possuindo competência constitucional para afastar a aplicabilidade de normas jurídicas eivadas de inconstitucionalidade, bem como para interpretá-las em conformidade com o texto constitucional, caminha-se no sentido de se admitir que qualquer relação jurídica privada possa ser objeto de análise de sua conformidade com o texto constitucional, seja mediante a eficácia direta ou indireta das normas de diretos fundamentais. A questão, portanto, desbordará e rendundará na análise da constitucionalidade das restrições estabelecidas aos direitos fundamentais em decorrência do exercício da autonomia privada e da liberdade de contratação, a partir da ponderação dos princípios constitucionais e ou bens constitucionais em conflito.

Nos casos em que o legislador densificou o conteúdo do direito fundamental, disciplinando a forma de sua aplicação às relações jurídicas privadas, duas situações podem se verificar. A primeira situação verificar-se-á quando se constatar a existência de normas infraconstitucionais que, a despeito de terem o propósito de densificar a aplicação de determinado direito fundamental às relações jurídicas entre os particulares, apresentam-se incompatíveis com o texto constitucional. Nesta hipótese, competirá ao intérprete promover a interpretação e aplicação da norma jurídica de direito privado em conformidade com o texto constitucional. Sendo impossível atribuir-lhe interpretação conforme a Constituição, outra medida não restará senão a declaração de sua inconstitucionalidade. A segunda situação verificar-se-á quando se constatar a existência normas infraconstitucionais que, a despeito de terem o propósito de densificar o conteúdo de direitos fundamentais, o fazem de forma insuficiente. Nesta hipótese competirá ao intérprete promover a integração do conteúdo das normas jurídicas de direito privado com o conteúdo das normas constitucionais de direitos fundamentais, em especial, mediante as cláusulas gerais e conceitos jurídicos indeterminados.

recorrer somente a esses últimos, sem que isso faça alguma diferença na definição do resultado." (SILVA, 2008, p. 142)

${ }^{45}$ NOVAIS, 2007, p. 232 
Em ambas situações, os órgãos jurisdicionais, em respeito ao princípio democrático e a separação de poderes, não poderão desprezar as decisões legislativas que estão materializadas nas normas jurídicas infraconstitucionais, salvo na hipótese de vício de inconstitucionalidade, situação na qual a norma jurídica deverá ser declarada inconstitucional e ter afastada sua aplicabilidade. ${ }^{46}$ Seja na hipótese em que se afasta a aplicabilidade de uma norma jurídica em decorrência de sua inconstitucionalidade, seja na hipótese de ser necessária a integração do conteúdo da norma jurídica de direito privado, por se entender que a densificação legislativa fora insuficiente, estar-se-á diante do reconhecimento da força normativa das normas de direitos fundamentais e sua capacidade de irradiar efeitos sobre as relações jurídicas privadas. ${ }^{47}$ Conforme destaca Silva:

Há, no entanto, diversas situações para as quais somente uma aplicação direta dos direitos fundamentais pode fornecer uma solução adequada. Essas situações são aquelas para as quais não há mediação legislativa ou que a atividade legislativa se tenha mostrado insuficiente. É na aplicação direta, portanto, que os problemas se tornam mais agudos, pois é nesses casos que os direitos fundamentais mais diretamente se chocam com a autonomia privada. A principal questão a ser resolvida nesse ponto é a forma de combinar essa autonomia com direitos fundamentais que, aplicados diretamente à relação entre particulares, tendem a eliminá-la (SILVA, 2008, p. 148).

Analisando profundamente a questão, verifica-se que, independentemente da adoção da eficácia imediata ou mediata dos direitos fundamentais, em razão da vinculação direta dos poderes constituídos às normas constitucionais, bem como dos deveres de proteção que lhe são inerentes, em especial, aos órgãos jurisdicionais, estes acabarão, ao final, chegando ao mesmo resultado, qual seja, a irradiação dos direitos fundamentais sobre o direito privado. ${ }^{48}$ Essa conclusão corrobora para a necessidade de se superar a dicotomia entre

\footnotetext{
${ }^{46}$ Conforme destaca Julio Estrada: "enun Estado de Derecho, y envirtuddel principio democrático, no cabe duda que élórgano que ostenta larepresentación popular há de gozar de laprimacia para laconcreción de losderechosfundamentalesenel ordenamento jurídico civil." (JULIO ESTRADA, 2000, p. 210) Em igual sentido, sustenta Steinmetzque,"em virtude dos princípios democráticos e da separação de poderes, não deve, de plano e sem a apresentação de razões jurídico-constitucionais de pose (ônus da argumentação), afastar-se da solução legislativa." (STEINMETZ, 2004, p. 26).

${ }^{47}$ Conforme destaca Perlingeri: "a norma constitucional pode, também sozinha (quando não existirem normas ordinárias que disciplinem a fattispecie em consideração) ser a fonte da disciplina de uma relação jurídica de direito civil." E conclui, "a normativa constitucional não deve ser considerada sempre e somente como mera regra hermenêutica, mas também como norma de comportamento, idônea a incidir sobre o conteúdo das relações entre situações subjetivas, funcionalizando-as aos novos valores." (PIERLINGERI, 2002, p 11)

${ }^{48}$ Essa afirmativa não indica que em todos os casos de conflitos de direitos fundamentais com a autonomia privada esta sempre terá sua eficácia afastada para dar lugar aos demais direitos fundamentais. Conforme se demonstrará ao longo do trabalho, a autonomia privada, enquanto
} 
eficácia imediata ou mediata, para buscar uma solução diferenciada para a eficácia do princípio da igualdade nas relações jurídica contratuais entre particulares, sem desprezar os contributos de cada uma das construções teóricas para a temática. Sobre a eficácia dos direitos fundamentais nas relações jurídicas privadas e a atuação dos órgãos jurisdicionais, destaca Canotilho que:

Os juízes, embora vinculados em primeira linha pela mediação legal dos direitos, liberdades e garantias, devem também dar operatividade prática à função de proteção (objectiva) dos direitos, liberdade e garantias. a) em primeiro lugar, devem fazer a aplicação do direito privado legalmente positivado em conformidade com os direitos fundamentais pela via da interpretação conforme a Constituição. b) se a interpretação conforme direitos, liberdades e garantias for insuficiente cabe sempre na competência dos tribunais a desaplicação da lei (por inconstitucional) violadora dos direitos (subjectivos) ou dos bens constitucionalmente garantidos pelas normas consagradoras de direitos fundamentais. c) a interpretação conforme os direitos, liberdades e garantias das normas de direito privado utilizará como instrumentos metódicos não apenas as clássicas cláusulas gerais ou conceitos indeterminados (boa-fé, abuso de direito), mas também as próprias normas consagradoras e defensoras de bens jurídicos absolutos (vida, liberdade). Trata-se, pois, de uma concretização de bens jurídicos constitucionalmente protegidos através de normas de decisão judiciais (CANOTILHO, 2003, p. 1292).

Essa perspectiva promove a superação de uma das premissas sob as quais a eficácia indireta se sustenta, uma vez que a irradiação dos efeitos das normas de direitos fundamentais não fica restrita nem condicionada à existência de cláusulas gerais ou conceitos jurídicos indeterminados, haja vista ser dever dos poderes constituídos, em razão de sua vinculação às normas constitucionais, dotadas de fundamentalidade, força normativa e superioridade hierárquica, atuar no sentido de garantir a máxima efetividade da Constituição. Dessa forma, quer o legislativo, ao elaborar normas jurídicas para concretizar e regulamentar a eficácia dos direitos fundamentais nas relações jurídicas privadas, quer os órgãos jurisdicionais ao apreciarem e julgarem litígios jurídicos entre particulares, quer o executivo ao dar executoriedade às normas jurídicas vigentes, por estarem vinculados aos direitos fundamentais tem o dever de impedir violações ao seu conteúdo, protegendo e garantindo a sua eficácia.

relevante direito fundamental, essência do Direito Privado e fonte dos negócios jurídicos, prevalecerá em inúmeras situações de conflito. Ademais enquanto direito fundamental, a autonomia privada também irradia seus efeitos por todo ordenamento jurídico. Conforme destacou Leisner, citado por Alexy, "o efeito perante terceiros será, no final de contas, sempre um efeito direto." (ALEXY, 2014, p. 540) 
Sustenta Vieira de Andrade que no direito português há tendência de se superar essa dicotomia entre eficácia imediata e mediata, para ampliar a vinculação do poder público no dever de garantir a efetividade dos direitos fundamentais, em nítida influência da teoria dos deveres de proteção. Assim, "quer o legislador, ao fazer as leis reguladoras das relações privadas, quer o juiz, ao resolver os conflitos entre particulares" por estarem vinculados aos direitos fundamentais, "teriam sempre de ter em conta e de aplicar os preceitos constitucionais respectivos"49 Aqui, todavia, há que se destacar que, conforme aduz Canotilho, os direitos fundamentais também não podem aspirar a se transformarem em uma força conformadora das relações privadas, uma vez que uma tal pretensão teria como consequência um confisco substancial da autonomia privada, compromentendo a capacidade dos indivíduos de livremente conformarem suas relações jurídicas e desenvolverem sua personalidade. ${ }^{50}$

A dicotomia entre eficácia direta e indireta das normas de direitos fundamentais perde parte de seu sentido no âmbito do ordenamento jurídico brasileiro, uma vez que as normas jurídicas de direito privado, inclusive e Lei de Introdução ao Código Civil, estão repletas de cláusulas gerais e conceitos jurídicos indeterminados, de modo que os órgãos jurisdicionais poderão promover com facilidade a irradiação do conteúdo dos direitos fundamentais para as relações jurídicas entre particulares, exemplificativamente, ao delimitar o conteúdo do que configura um abuso de direito, definir que condutas caracterizam o cumprimento da função social da propriedade, posse ou contrato, bem como quando se esta diante da violação da boafé objetiva ou dos bons costumes.

Esse talvez seja um dos motivos pelos quais a questão da eficácia dos direitos fundamentais nas relações jurídicas entre particulares não tenha sido objeto de intensos e profundos debates pelos estudiosos dos direitos fundamentais, nem mesmo sido utilizada como fundamento para a resolução de casos concretos em que haja notório conflito de direitos fundamentais nas relações jurídicas privadas. Os órgãos jurisdicionais tem se valido das cláusulas gerais do abuso de direito, da boa-fé, dos bons costumes para resolver os conflitos entre a autonomia privada e liberdade contratual e os demais direitos fundamentais, principalmente nas relações de natureza consumerista, quando considera abusivas cláusulas contratuais que restrinjam em demasia os direitos fundamentais dos consumidores.

O princípio da competência decisória de legislador expressa a ideia de que as decisões legislativas devem ser respeitadas na maior medida do possível, observadas as condições

\footnotetext{
${ }^{49}$ VIEIRA DE ANDRADE, 2009, p. 241.

${ }^{50}$ CANOTILHO, 2003, p. 1293
} 
fáticas e jurídicas do caso concreto. Assim, a atividade mediadora concretizadora a ser realizada pelo legislador deve ser considerada válida, não pelo seu conteúdo, que deverá ser objeto de controle de constitucionalidade, mas sim, pelo simples fato de que as normas jurídicas concretizadoras do conteúdo dos direitos fundamentais nas relações jurídicas privadas estarem assentadas no exercício da competência democrática pelo legislador, bem como em respeito ao princípio da separação dos poderes. ${ }^{51}$ Destaque-se que as decisões legislativas materializadas mediante a edição de normas infraconstitucionais poderão ter seu sentido reconstruído, a partir da interpretação conforme a Constituição, de modo a garantir a máxima efetividade das normas constitucionais, ou ter sua aplicabilidade afastada nos casos de contrariedade de seu conteúdo com qualquer norma constitucional. ${ }^{52}$

Conforme destaca Sarmento, os órgãos jurisdicionais não podem agir como se o ordenamento jurídico fosse um sistema composto apenas por princípios, competindo-lhes toda a tarefa de concretização dos direitos fundamentais, comportando-se como se as regras não existissem. Nos casos em que os órgãos legislativos promoveram a concretização do conteúdo das normas de direitos fundamentais, editando normas jurídicas dotadas de presunção de constitucionalidade, surge para os órgãos jurisdicionais, no mínimo, o ônus argumentativo de demonstrar a incompatibilidade da concretização realizada com a ordem constitucional ou sua eventual insuficiência, pois "do contrário, abre-se a porta ao arbítrio e ao decisionismo, em prejuízo da segurança jurídica e da democracia." ${ }^{\text {"53 }}$ Os órgãos jurisdicionais não podem se transformar em substitutos do poder legislativo, se imiscuindo em sua competência, devendo observar as decisões legislativas assentadas no princípio democrático.

\footnotetext{
51 Importante destacar que todas as normas constitucionais vigentes são dotadas de presunção relativa de constitucionalidade, que pode ser absolutizada pela via das ações do controle de constitucionalidade ou afastada pelos controles difuso ou concentrado de constitucionalidade.

52 No entendimento de Sarmento, "Portanto, quando o legislador já tiver concretizado alguma norma constitucional mais vaga, ou equacionado normativamente uma tensão entre princípios e valores constitucionais colidentes, a solução legislativa deve ser acatada pelo Judiciário na solução do caso, a não ser que se afigure incompatível com a própria Constituição, em abstrato ou na hipótese concreta." (SARMENTO, 2007, p. 142) E conclui, "a constitucionalização do Direito pela filtragem constitucional não deve ser levada ao ponto de confiscar a liberdade decisória que, numa democracia, deve caber ao legislador. Afinal, sendo o constitucionalismo uma técnica de combate do autoritarismo, seria altamente paradoxal converter a Constituição num instrumento autoritário de modelação de todos os espaços da vida social nas mãos de juízes não eleitos." (SARMENTO, 2007, p. 142)

${ }^{53}$ ALEXY, 2014, p. 147
} 


\section{CONSIDERAÇÕES FINAIS}

Uma das temáticas mais controversas e que tem despertado o interesse de inúmeros estudiosos é aquela relativa à eficácia dos direitos fundamentais no âmbito das relações jurídicas entre particulares, em especial, quando o objetivo é definir a extensão da eficácia dos direitos fundamentais nessas relações jurídicas, o qual demanda, necessariamente, a análise das relações existentes entre as normas jurídicas constitucionais e as normas jurídicas de direito privado, bem como o conflito entre direitos fundamentais concretizado no âmbito de relações jurídicas privadas.

O trabalho teve o objetivo de proceder ao estudo da eficácia do princípio da igualdade no âmbito das relações jurídicas entre particulares, com o intuito de contribuir para os debates existentes e aperfeiçoamento das construções teóricas, na tentativa de formular proposições adequadas, capazes de conciliar a tutela do princípio da igualdade e sua correlata proibição de práticas discriminatórias, com a necessidade em se conferir segurança jurídica a estas relações jurídicas, mediante a proteção da autonomia privada e da liberdade contratual, corolários do direito fundamental ao livre desenvolvimento da personalidade.

A questão da eficácia dos direitos fundamentais nas relações jurídicas privadas, exige, na atualidade, a adoção de soluções diferenciadas, que não se limitem a defender de maneira uniforme uma eficácia imediata ou mediata. A exigência por soluções diferenciadas decorre, principalmente, da necessidade de que a questão seja sempre analisada a partir dos direitos fundamentais em colisão, bem como as especificidades do caso concreto. Ademais, a questão da eficácia dos direitos fundamentais nas relações jurídicas entre particulares não deve ser analisada a partir do pressuposto de que eficácia imediata e mediata são formas incompatíveis e excludentes de incidência dos direitos fundamentais nas relações jurídicas privadas.

A atividade legislativa nem sempre conseguirá disciplinar e concretizar o conteúdo das normas de direitos fundamentais nas relações jurídicas privadas, nem mesmo problematizar e estabelecer soluções prévias para todos os conflitos jurídicos possíveis. Nessas situações, em que o legislador for omisso, uma vez que não é plausível acreditar ou confiar em sua onisciência, os órgãos jurisdicionais assumirão a função de concretizar o conteúdo dos direitos fundamentais no âmbito daquela relação jurídica entre particulares, seja mediante a interpretação das cláusulas gerais ou conceitos jurídicos indeterminados, seja pela interpretação das normas jurídicas de direito privado vigentes em conformidade com o texto 
constitucional, ou, inclusive, pela aplicabilidade direta do conteúdo dos direitos fundamentais nas relações jurídicas privadas, em razão de sua dimensão objetiva e seu efeito irradiador.

Quando se constatar a existência de normas infraconstitucionais que, a despeito de terem o propósito de densificar a aplicação de determinado direito fundamental às relações jurídicas entre os particulares, apresentam-se incompatíveis com o texto constitucional, competirá ao intérprete promover a interpretação e aplicação da norma jurídica de direito privado em conformidade com o texto constitucional. Sendo impossível atribuir-lhe interpretação conforme a Constituição, outra medida não restará senão a declaração de sua inconstitucionalidade. Quando se constatar a existência normas infraconstitucionais que, a despeito de terem o propósito de densificar o conteúdo de direitos fundamentais, o fazem de forma insuficiente, competirá ao intérprete promover a integração do conteúdo das normas jurídicas de direito privado com o conteúdo das normas constitucionais de direitos fundamentais, em especial, mediante as cláusulas gerais e conceitos jurídicos indeterminados.

Em ambas as situações, os órgãos jurisdicionais, em respeito ao princípio democrático e da separação de poderes, não poderão desprezar as decisões legislativas que estão materializadas nas normas jurídicas infraconstitucionais vigentes, exceto na hipótese de vício de inconstitucionalidade, situação na qual a norma jurídica deverá ser declarada inconstitucional e ter afastada sua aplicabilidade. Seja na hipótese em que se afasta o conteúdo de uma norma jurídica em decorrência de sua inconstitucionalidade, seja na hipótese de ser necessária a integração do conteúdo de norma jurídica de direito privado, por se entender que a densificação realizada pelo legislador se deu de forma insuficiente, estar-se-á diante do reconhecimento da força normativa das normas veiculadoras de direitos fundamentais e sua capacidade de irradiar efeitos sobre as relações jurídicas privadas.

Não se pode olvidar que os órgãos jurisdicionais não podem agir como se o ordenamento jurídico fosse um sistema composto apenas por princípios, competindo-lhes toda a tarefa de concretização dos direitos fundamentais, comportando-se como se as regras não existissem. Nos casos em que os órgãos legislativos promoveram a concretização do conteúdo das normas de direitos fundamentais, editando normas jurídicas dotadas de presunção de constitucionalidade, surge para os órgãos jurisdicionais, no mínimo, o ônus argumentativo de demonstrar a incompatibilidade da concretização realizada com a ordem constitucional ou sua eventual insuficiência, sob pena de estar-se permitindo o decisionismo jurídico. Deve-se observar a principiologia própria e inerente ao direito privado, a qual não pode ser simplesmente desconsiderada. 
Não se deve partir do pressuposto de que a ausência de normas juríicas de direito privado decorre de uma omissão legislativa, uma vez que, em inúmeras situações, a ausência de normatização específica decorre do reconhecimento de que, naquela situação, deverá prevalecer a competência decisória dos particulares na conformação de seus negócios jurídicos, a qual sofrerá restrições pelos princípios gerais do direito privado, pelo respeito à ordem pública e ao direito de terceiros. Não se pode olvidar que o princípio da legalidade, uma das mais relevantes garantias fundamentais, estabelece que, no âmbito das relações jurídicas privadas, aquilo que não éproibido insere-se dentro do espaço de liberdade individual, sendo, portanto, permitido, desde que o exercício da liberdade não afronte a ordem jurídica, em especial, ao conteúdo da dignidade da pessoa humana.

\section{REFERÊNCIAS}

ABRANTES. João José Nunes. A vinculação das entidades privadas aos direitos fundamentais. Lisboa: Associação Acadêmica da Faculdade de Direito de Lisboa, 1990.

ALFARO AGUILA-REAL, Jesús. Autonomia privada y derechosfundamentales. Anuario de Derecho Civil, 1993, p. 57-122.

ALEXY, Robert. Teoria dos Direitos Fundamentais. José Afonso da Silva (Trad.).São Paulo: Malheiros, 2014.

BILBAO UBBILOS, Juan Maria. Los derechosfundamentales em lafrontera entre lo público y lo privado: lanoción de stateactionenlajurisprudencianorteamericana. Madri: McGraw-Hill. 1997.

BILBAO UBILLOS, Juan Maria. La eficácia de losderechosfundamentales frente a particulares. Madrid: Centro de Estúdios Políticos y Constitucionales, 1997.

BILBAO UBILLOS, Juan Maria. La eficacia frente aterceros de losderechosfundamentales em elordenamientoespañol. In: MONTEIRO, António Pinto; NEUNER, Jorg; SARLTET, Ingo Wolfgang. (Orgs.). Direitos fundamentais e direito privado: uma perspectiva de direito comparado. Coimbra: Almedina, 2007, p.145-163.

BILBAO UBILLOS, Juan Maria. ¿Enqué medida vinculan a los particulares losderechosfundamentales? In: SARLET, Ingo (Org.). Constituição, Direitos Fundamentais e Direito Privado. $2^{a}$ ed. rev. ampl. Porto Alegre: Livraria do Advogado, 2006. p. 301-340.

BOCKENFORDE, Ernest Wolfgang. Escritos sobre derechosfundamentales. Juan LuisRequejoPagés (Trad.). Baden-Baden: Nomos Verlsagsgesellschaft, 1993.

BONAVIDES, Paulo. Curso de direito constitucional. 23ª ed. São Paulo: Malheiros, 2008. 
BRANCO, Paulo Gustavo Gonet. Aspectos de Teoria Geral dos Direitos Fundamentais. In: MENDES, Gilmar Ferreira; COELHO, Inocêncio Mártires; BRANCO Paulo Gustavo Gonet. Hermenêutica Constitucional e Direitos Fundamentais. Brasília: Brasília Jurídica, 2000.

CANARIS, Claus-Wilhelm. Direitos fundamentais e direito privado. SARLET, Ingo Wolfgang; PINTO, Paulo Mota. (Trad.) Coimbra: Almedina, 2003.

CANARIS, Claus-Wilhelm. Pensamento sistemático e conceito de sistema na ciência do direito. Antônio Menezes Cordeiro (Trad.). 2a ed. Lisboa: Fundação CalousteGulbenkian, 1996.

CANOTILHO, José Joaquim Gomes. Direito constitucional e teoria da Constituição. $7^{\mathrm{a}}$ ed. Coimbra: Almedina, 2003a.

CANOTILHO, José Joaquim Gomes. Civilização do Direito Constitucional ou Constitucionalização do Direito Civil? A eficácia dos direitos fundamentais na ordem jurídico-civil no contexto do direito pós-moderno. In: GRAU, Eros Roberto; GUERRA FILHO, Willis Santiago. (Orgs.) Direito Constitucional. Estudos em Homenagem a Paulo Bonavides. $1^{a}$ ed., São Paulo: Malheiros Editores, p. 108-113, 2003 b.

CANOTILHO, Joaquim José Gomes. Dogmática de Direitos Fundamentais e Direito Privado. In: CANOTILHO, Joaquim José Gomes. Estudos sobre Direitos Fundamentais. Coimbra (Portugal): Coimbra Editora, 2004. p.190-215.

CRUZ, Álvaro Ricardo de Souza. Hermenêutica jurídica e(m) debate: o constitucionalismo brasileiro entre a teoria do discurso e a ontologia existencial. Belo Horizonte: Fórum, 2005.

CRUZ, Álvaro Ricardo de Souza. Habermas e o direito brasileito. $2^{\mathrm{a}}$ ed. Rio de Janeiro: Lúmen Iuris, 2007.

DURIG, Gunther. Grundrechte und Zivilrechtsprechung. In: Maunz, Theodor (Hrsg.); Vom Bonner GrundgesetzzurgesamtdeutschenVerfassung - Festschrift zum 75. Geburtstagvon Hans Nawiasky, München, 1956.

HABERMAS, Jürgen. Direito e democracia: entre faticidade e validade. Flávio BenoSiebeneichler (Trad.) Rio de Janeiro: Tempo Brasileiro, vol. I., 1997.

HABERMAS, Jürgen. Direito e democracia: entre faticidade e validade. Flávio BenoSiebeneichler (Trad.) Rio de Janeiro: Tempo Brasileiro, vol. II., 1997.

HESSE, Konrad. Derecho constitucional y derecho privado. Ignácio Gutiérrez (Trad.). Madrid: Civitas, 1955, 88 p.

HESSE, Konrad. A força normativa da Constituição. Gilmar Ferreira Mendes (Trad.) Porto Alegre: Sérgio Antônio Fabris, 2009.

HESSE, Konrad. Elementos de Direito Constitucional da República Federal da Alemanha. Luís Afonso Heck (Trad). Porto Alegre; Sérgio Antônio Fabris, 1998. 
JULIO ESTRADA, Alexei. La eficacia de losderechosfundamentales entre particulares.Colombia: Universidad Externado de Colombia, 2000, 332 p.

JULIO ESTRADA, Alexei. La eficacia entre particulares de losderechosfundamentales. Una presentacióndel caso colombiano. In: CARBONELL, Miguel. (Coord.). Derechosfundamentales y Estado. Ciudad de México: Universidad Autónoma de Mexico. 2002, p. 267-296.

LEISNER, Walter. Grundrechteundprivatrecht.Munique, 1960.

MC CRORIE, Benedita Ferreira da Silva. A vinculação dos particulares aos direitos fundamentais. Coimbra: Almedina, 2005.

NEUNER, Jorg. A influência dos direitos fundamentais no direito privado alemão. In: MONTEIRO, António Pinto; NEUNER, Jorg; SARLTET, Ingo Wolfgang. (Orgs.). Direitos fundamentais e direito privado: uma perspectiva de direito comparado. Coimbra: Almedina, 2007, p.213-236.

NOVAIS, Jorge Reis. Os direitos fundamentais nas relações jurídicas entre particulares. In: SARMENTO, Daniel Antônio de Moraes. (Org.). A Constitucionalização do Direito. Rio de Janeiro: Lúmen Iuris, 2007.

PEREZ LUÑO, Antônio Enrique. Los derechosfundamentales. 9ª ed. Madrid: Tecnos, 2007, $234 \mathrm{p}$.

PERLINGIERI, Pietro. Perfis do direito civil: introdução ao direito civil constitucional. Rio de Janeiro: Renovar, 1999. 359p.

QUEIROZ, Cristina M.M. Direitos fundamentais: teoria geral. Coimbra: Coimbra Editora, 2002.

SARLET, Ingo Wolfgang. A Constituição concretizada: construindo pontes entre o público e o privado. Porto Alegre: Livraria do Advogado, 2000a.

SARLET, Ingo Wolfgang. A eficácia dos direitos fundamentais, $8^{\mathrm{a}}$ edição, revista, atualizada e ampliada. 8a . ed. Porto Alegre: Editora Livraria do Advogado, 2007a. 503 p.

SARLET, Ingo Wolfgang. Dignidade da pessoa humana e direitos fundamentais na Constituição Federal de 1988. Porto Alegre: Livraria dos Advogados, 2001, 152p.

SARLET, Ingo Wolfgang. Direitos fundamentais e direito privado: algumas considerações em torno da vinculação dos particulares aos direitos fundamentais. Revista de Direito do Consumidor, São Paulo, v. 36, p. 54-104, 2000.

SARLET, Ingo Wolfgang. (Org.). O direito público em tempos de crise: estudos em homenagem a Ruy Ruben Ruschel. Porto Alegre: Livraria do Advogado, 1999.

SARMENTO, Daniel Antonio de Moraes. A dimensão objetiva dos direitos fundamentais: fragmentos de uma teoria. Revista de Direito da Associação dos Procuradores do Novo Estado do Rio de Janeiro, v. XII, p. 297-332, 2003. 
SARMENTO, Daniel Antonio de Moraes. A normatividade da constituição e a constitucionalização do Direito Privado. Revista da Escola da Magistratura do Estado do Rio de Janeiro, Rio de Janeiro, v. 6, n. 23, p. 272-297, 2003.

SARMENTO, Daniel Antonio de Moraes. Direitos fundamentais e relações privadas. $2^{\mathrm{a}}$ ed. Rio de Janeiro: Renovar, 2008, 362 p.

STEINMETZ, Wilson. A vinculação dos particulares a direitos fundamentais. São Paulo: Malheiros Editores, 2004.

STEINMETZ, Wilson. Direitos fundamentais e relações entre particulares: anotações sobre a teoria dos imperativos de tutela. Revista Brasileira de Direito Constitucional, Brasília, n. 5, jan./jun. de 2005.

STERN, Klaus. Derecho Del Estado de la Republica Federal Alemana. Javier Pérez Royo e Pedro Cruz Villalón (Trad.). Madrid: Centro de EstudiosConstitucionales, 1987.

SILVA, Virgílio Afonso da.A constitucionalização do direito: os direitos fundamentais nas relações entre particulares. São Paulo: Mandamentos, 2008.

SILVA, Virgílio Afonso da.Direitos fundamentais: conteúdo essencial, restrições e eficácia. São Paulo: Malheiros, 2009. 280 p.

SOMBRA, Thiago Luís Santos. A eficácia dos direitos fundamentais nas relações jurídico-privadas: a identificação do contrato como ponto de encontro dos direitos fundamentais. Porto Alegre: Sergio Antônio Fabris, 2004. 214 p.

TEPEDINO, Gustavo. Introdução: Código Civil, os chamados microssistemas e a Constituição: premissas para uma reforma legislativa. In: TEPEDINO, Gustavo. (Org.). Problemas de Direito Civil-Constitucional. Rio de Janeiro: Renovar, 2000.

VALE, André Rufino do. A eficácia dos direitos fundamentais nas relações privadas. Porto Alegre: Sergio Antonio Fabris Editor, 2004.

VALE, André Rufino. Drittwirkung de direitos fundamentais e associações privadas. Revista de Direito Público, n. ${ }^{\circ}$ 9, p. 53-74, jul/ago/set. 2005.

VIERA DE ANDRADE, José Carlos. Os direitos fundamentais na Constituição portuguesa de 1976. $3^{\text {a }}$ ed. Coimbra: Almedina, 1998. 